\title{
Why do We Want Trees? Potential for Improvement in Food and Income in Brazilian
}

\section{Rural Settlements}

Por Que Queremos Árvores? Potencial Para Melhoria da Alimentação e Renda em

\section{Assentamentos Rurais Brasileiros}

Bruna Aparecida da Silva ${ }^{1}$, Adriana Cavalieri Sais ${ }^{2}$ Eliana Cardoso-Leite ${ }^{3}$, Renata Evangelista de

\section{Oliveira $^{4}$}

DOI: https://doi.org/10.52719/bjas.v2i2.3774

\section{ABSTRACT}

The aim of this study was to investigate tree species cultivated and maintained by family farmers in five rural settlements, to understand the motivations for farmers to cultivate them and analyze their potential to provide income and food improvement. We have studied trees distribution in 16 lots and surveyed tree species cultivated by farmers, as well as their functions within the lots. We listed food and medicinal species, and those already commercialized, and the main market channels for their products. The main reason the families cultivate or maintain trees in their lots is for food supply but there are other motivations, related to well-being and cultural issues. Farmers plant trees motivated mainly by direct use (food) and for the possibility of generating income through the sale of tree products. We found 92 tree species, being half of them cultivated for food and medicinal uses. Approximately $45 \%$ of these species are commercialized by farmers in different channels. We conclude that trees are important for farming and livelihoods in rural settlements and have potential to be inserted in local productive systems.

Keywords: Family farming. Agroecosystems. Trees. Livelihoods.

\section{RESUMO}

O objetivo deste estudo foi investigar as espécies arbóreas cultivadas e mantidas por agricultores familiares em cinco assentamentos rurais, a fim de entender as motivações para os agricultores cultivá-las e analisar seu potencial para proporcionar renda e melhoria alimentar. Estudamos a distribuição de árvores em 16 lotes e pesquisamos espécies de árvores cultivadas

\footnotetext{
${ }^{1}$ Universidade de São Paulo

${ }^{2}$ Universidade Federal de São Carlos (UFSCar)

${ }^{3}$ Universidade Federal de São Carlos (UFSCar)

${ }^{4}$ Universidade Federal de São Carlos (UFSCar)
} 

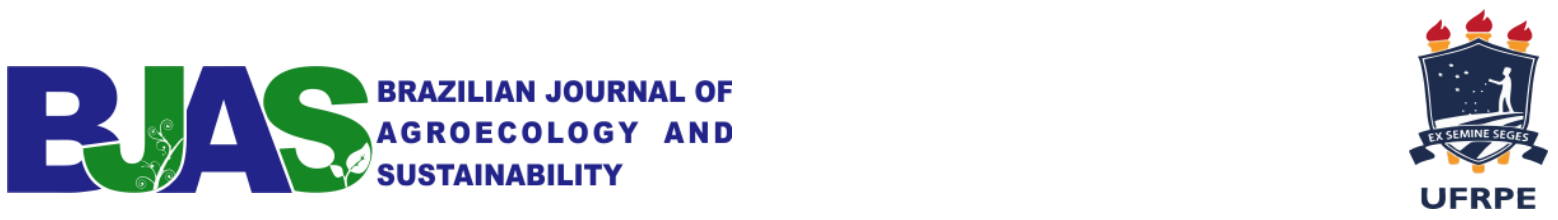

por agricultores, bem como suas funções dentro dos lotes. Listamos as espécies alimentares e medicinais, aquelas já comercializadas, e os principais canais de comercialização para seus produtos. A principal razão pela qual as famílias cultivam ou mantêm árvores em seus lotes é para alimentação, mas existem outras motivações, relacionadas ao bem estar e a aspectos culturais. Os agricultores plantam árvores motivados principalmente pelo uso direto (alimentos) e, também, pela possibilidade de gerar renda através da venda de produtos arbóreos. Encontramos 92 espécies de árvores, sendo metade delas cultivada para fins medicinais e alimentares. Aproximadamente $45 \%$ dessas espécies são comercializadas pelos agricultores em diferentes canais. Concluímos que as árvores são importantes para a agricultura e meios de subsistência em assentamentos rurais e têm potencial para serem inseridas nos sistemas produtivos locais.

Palavras-chave: Agricultura familiar. Agroecossistemas. Árvores. Modos de vida.

\section{INTRODUCTION}

\footnotetext{
"The unsustainability of modern conventional agriculture points to the need of creating social and ecological alternatives that can surpass it." (Bozzo \& Figueiredo, 2018, p. 88)
}

Rural areas in Brazil are characterized by great inequality with predominance of largescale monocultures. In this context, social programs of agrarian reform (establishing settlement projects) aim to ensure access to land for small farmers, promoting social justice, improving the living conditions of populations and strengthening family farming (Miranda \& Carmo, 2009; Herrera, Sabatino, Jaimes, \& Saura, 2017; Farias, Beltrão, Santos, \& Cordeiro, 2018). In addition to reducing inequality, the search for "more sustainable agriculture" must balance its productive, economic, ecological, and social functions, and design new landscapes, that contain more friendly agroecosystems, socially and environmentally (Landis, 2017). These "multifunctional landscapes" must provide food security and the maintenance of ecological functions, in addition to providing aesthetic and cultural services (O'Farrell \& Anderson, 2010). To build them, it is necessary to create new productive arrangements in agroecosystems.

Diversification within these agroecosystems should be guided by agroecological transition processes (Altieri, 2002), and generate new food systems, where trees can perform multiple functions (Chirwa \& Mala, 2016), supplying timber and non-timber products, generating income and food. According to Altieri (2002) perennial crops tend to generate more stable and diversified agroecosystems, which is beneficial for agroecological transition 

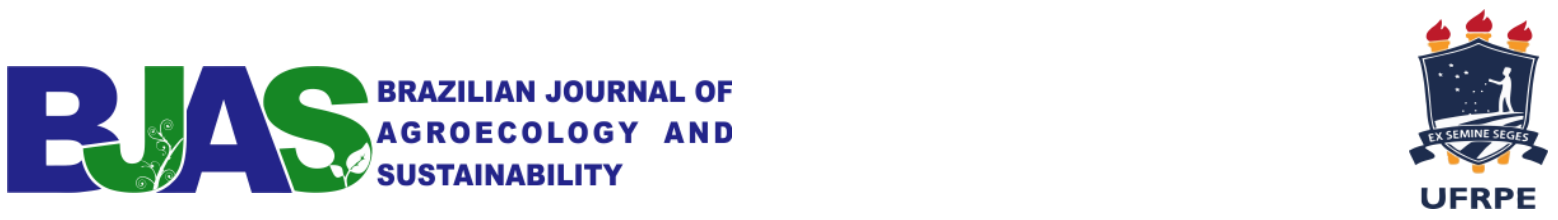

processes. It is important to notice that the presence of trees and their insertion in productive systems is related to farmers' acceptance and perception about the different functions they can perform (Piasentin, Saito, \& Sambuichi, 2014) and, in rural settlements, trees can contribute to the improvement of livelihoods, providing food and income (Mbow et al., 2013; Adane, Legesse, Weldeamanuel, \& Belay, 2019). In these areas, studying the agroecosystems formed within the lots, from the decision and management by the farmers, can help to understand the role of different components (as trees) in productive development, income generation, wellbeing, health and food security of rural families.

The land use and occupation model in Brazil has mostly been - and continues to be based on the principle that native forest cover and its biodiversity are obstacles to the establishment of any production system, and for that, they need to be removed (Ramos, Szmrecsányi, \& Pellegrini, 2010). The state of São Paulo has 188,620 rural establishments, comprising a total area of approximately 16.5 million ha (Instituto Brasileiro de Geografia e Estatística [IBGE], 2017). From these, 65\% is occupied with family farming. Rural settlements in Brazil are a result from long processes of struggle of men and women to the right to land. Most of the times, many of these lands are already degraded. According to Ramos et al. (2010) in plots with small areas, these farmers have been looking for productions initially aimed at family self-consumption and trying to access and entering the established markets, with greater added values to their products, given the impossibility of expanding their cultivated areas.

The aim of this study was to investigate arboreal species cultivated and maintained by family farmers in five rural settlements in the city of Araras, São Paulo (Brazil), in order to understand the motivations for farmers to cultivate them and analyze their potential to provide income and food improvement.

\section{METHODOLOGY}

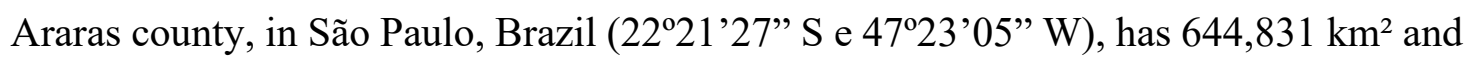
118.843 inhabitants (IBGE, 2010), being 112.444 (94,6\%) in urban areas and $6.399(5,4 \%)$ in the rural zone. There are 358 rural properties, and they sum 50,483 hectares, that is, $78 \%$ of the county total area (IBGE, 2017). Sugarcane monoculture accounts for 53\% of their total land use, and there are only $15 \%$ covered with native vegetation (Atlantic Forest and Cerrado). Only 2,491 properties are family farms, and beside them, there are 109 properties (lots) in five rural settlements (named Araras I, II, III, IV, and Saltinho) (Fundação Instituto de Terras do Estado de São Paulo [ITESP], 2007). 

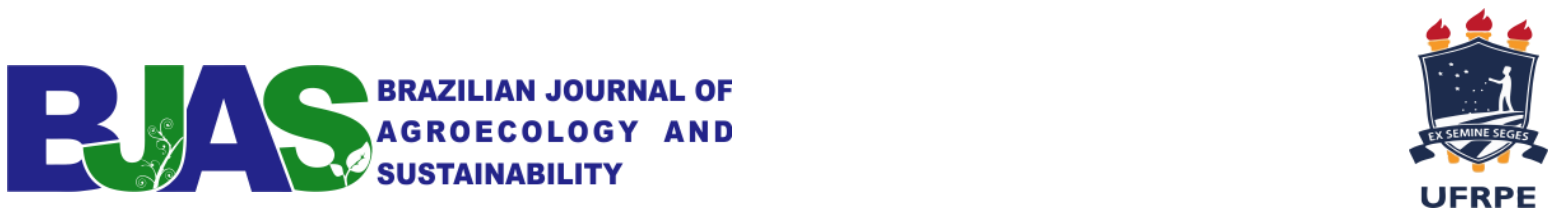

We used GIS (QGIS 3.0.1 - Girona) to map and perform a spatial analysis of the 109 lots, identifying those with trees presence in their different arrangements (isolated trees, trees nuclei, hedgerows, and commercial plantings) (Figure 1). After mapping, GIS was used to raffle lots to be visited. The choice was made randomly in the total area of the settlements, selecting 16 lots $-15 \%$ of total (four for each type of arrangement - isolated trees, tree core, border planting and tree plantations), in which the trees were inserted or maintained in the lots by choice of settlers, and not by legal obligation (outside protected areas). The species identification was checked and confirmed in Brazil's Flora Online and The Plant List. We interviewed the settled farmers, to identify these trees' role in production systems and local livelihoods, and their reasons (main motivations) to want trees in their lots. To analyze tree species potential for food improvement and in income generation, we listed those used for food and medicinal uses, and those which are sold by the farmers, and their main commercialization channels. 

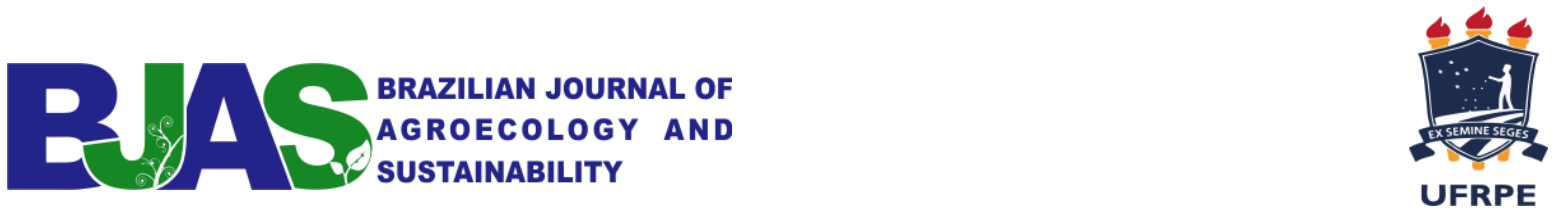

Figure 1 - Rural settlements, protected areas, and areas with the arboreal component - planted and maintained by farmers (in a sketch and overlapping on an image map of the municipality of Araras-SP, Brazil, highlighting the little existing native forest cover).

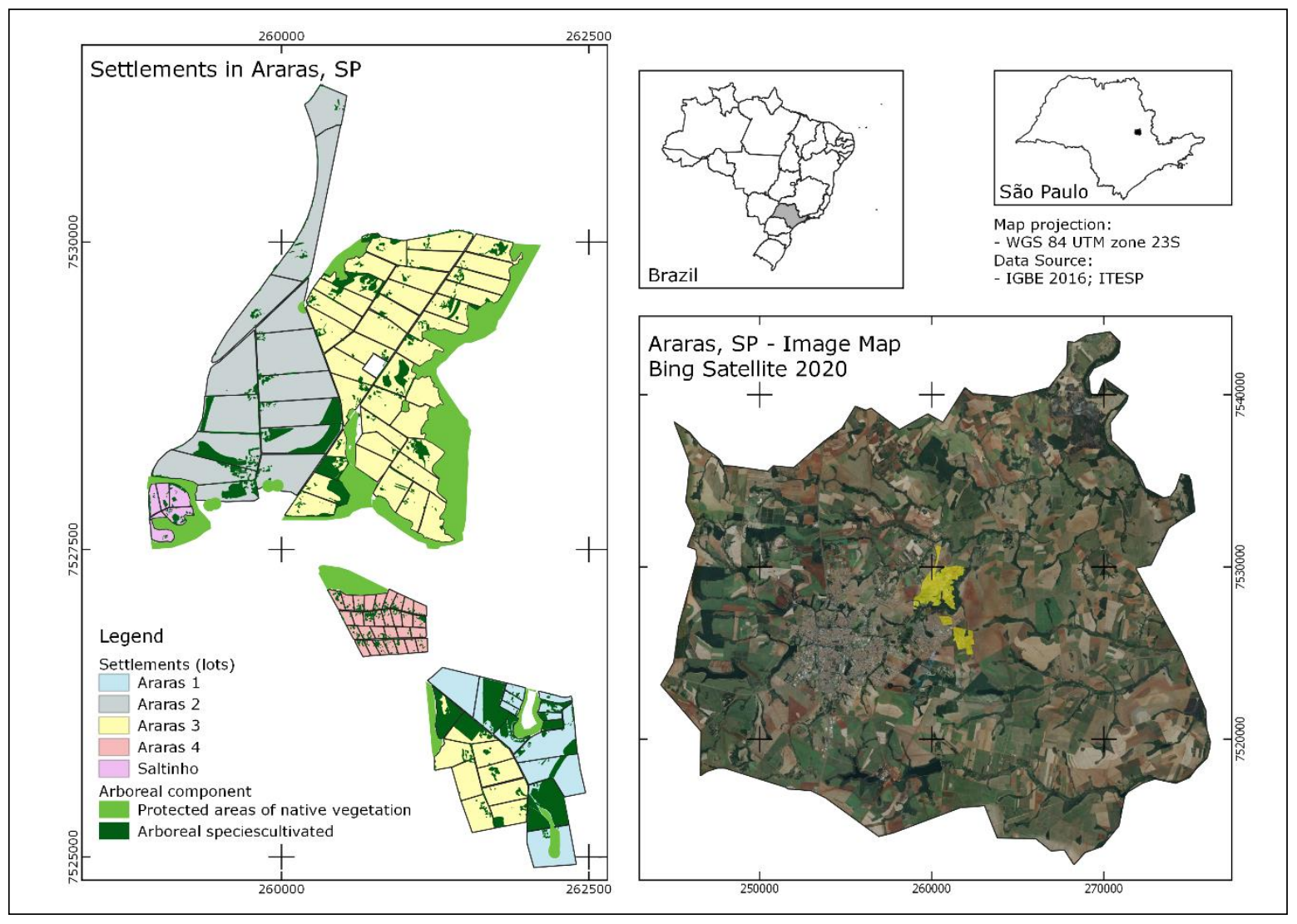

Source: Elaborated by the author.

\section{RESULTS AND DISCUSSION}

\section{The choice of species by farmers and the benefits from trees}

"Forest and tree products enter people's lives as goods and services, fulfilling basic subsistence needs for food, shelter, energy and health, amongst others. They may be traded near and far from their place of origin. They may be used for everyday activities, as exotic luxury items, or hold great cultural or symbolic value for worship. The activities and processes arising when such products enter new environments can have local as well as far-reaching ecological, social, and economic consequences. Money is made and lost. Livelihoods and ecosystems are impacted, both positively and negatively. Landscapes change. Organizations and institutions arise and fall around products, and cultures are both affected and shaped by the value chains that arise from the movement of products harvested from forests and farms, transported - processed and transformed into other products - marketed, sold, consumed and discarded" (Ingram et al., 2014, p. 1).

Involving both local men and women and understanding the formal management of their own environments builds on people's experiential knowledge, their capabilities, goals, and 

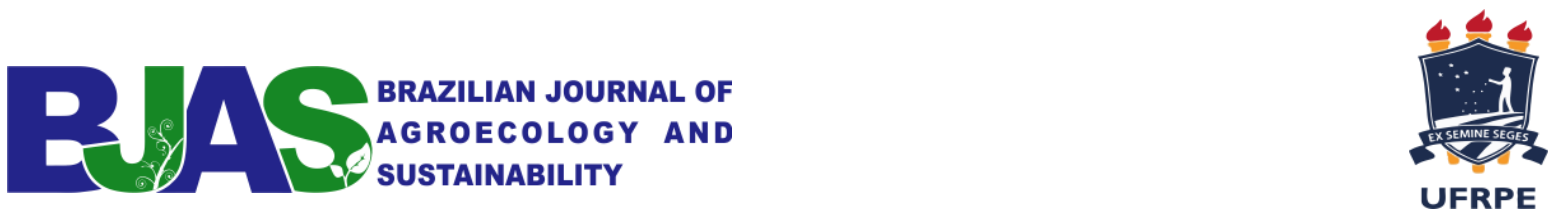

ways of life, different realms of expertise and different environmental interests (Colfer et al., 2015). According to Cruz (2008), men and women in agrarian reform settlements are active participants in the process of fighting for land, but they have different interpretations of the world, even if they are engaged in the same groups in these settlements. This author says that beneficiaries of agrarian reform do not have a unique identity and are not a homogeneous social group, and that it is important to understand the production of territories in settlements through their culture, desires, and perceptions. To this author: "Land reform settlers produce different territorialities in rural settlements, based on their ways of life, and produce land reform in their own way, according to their perspective of land use and appropriation" (Cruz, 2008, p. 98).

Studying the arboreal component within settlements, their acceptance by farmers, the cultivated species and the role they play within the lots can enable new forms of spatial organization and design, with innovations in production processes, environmental conservation and market insertions (Duque-Brasil et al., 2011; Chirwa \& Mala, 2016). Mbow et al. (2013) claim that tree-based systems are more productive and more aligned with the material and cultural needs of human populations than systems that do not contain the tree component.

In addition to generate income, services, and livelihoods for farmers, as already highlighted in this text, trees can also be part of the local culture, as well as being of personal interest to each farmer, representing beauty, well-being, recreation, and religiosity. Thus, it is evident the existence of a relationship between farmers and trees, emphasizing anthropocentric values and the importance of tree species that are desired by farmers, as a means for their satisfaction, in addition to their economic and useful values (Piasentin et al., 2014; Chan, Gold, \& Pascual, 2018; Cooper, Bradyc, Steend, \& Bryced, 2016).

The interviewed farmers in our research are the owners of the lots, all settled for more than ten years and belonging to the countryside since childhood. Of the 16 farmers who participated in the interviews, eight were men (50\%), six women (37.5\%), and in two lots the couple answered the questions together (12.5\%). The interviewees' ages ranged from 43 to 72 years, but there was no difference in knowledge about tree species. We found 92 tree species cultivated by them, in 38 botanical families. From these, 47 are native species $(51.09 \%), 31$ exotic species (33.70\%) and 14 naturalized (15.21\%).

The farmers reported that the natural resources available when they occupied the lots were very scarce, and there was no cultivation, which is what, according to them, led them to start planting trees quickly. This attitude itself indicates the willingness of farmers to grow trees. It can also be said that the introduction and maintenance of trees in the lots is a personal choice 
of the settlers, since there is no legal obligation in Brazil to maintain the tree component outside protected areas.

In agreement with Oli, Treue and Larsen (2015), which highlights the cultivation of multipurpose trees on agricultural lands, meeting the subsistence needs of farmers, in this study most species have more than one function for families. The main motivations to maintain them, are described in Figure 2, constructed using the number of citations for each different function (or reason to maintain) the tree species, in the interviewed lots.

Figure 2: Number of times each function was cited, for different tree species, during the interviews.

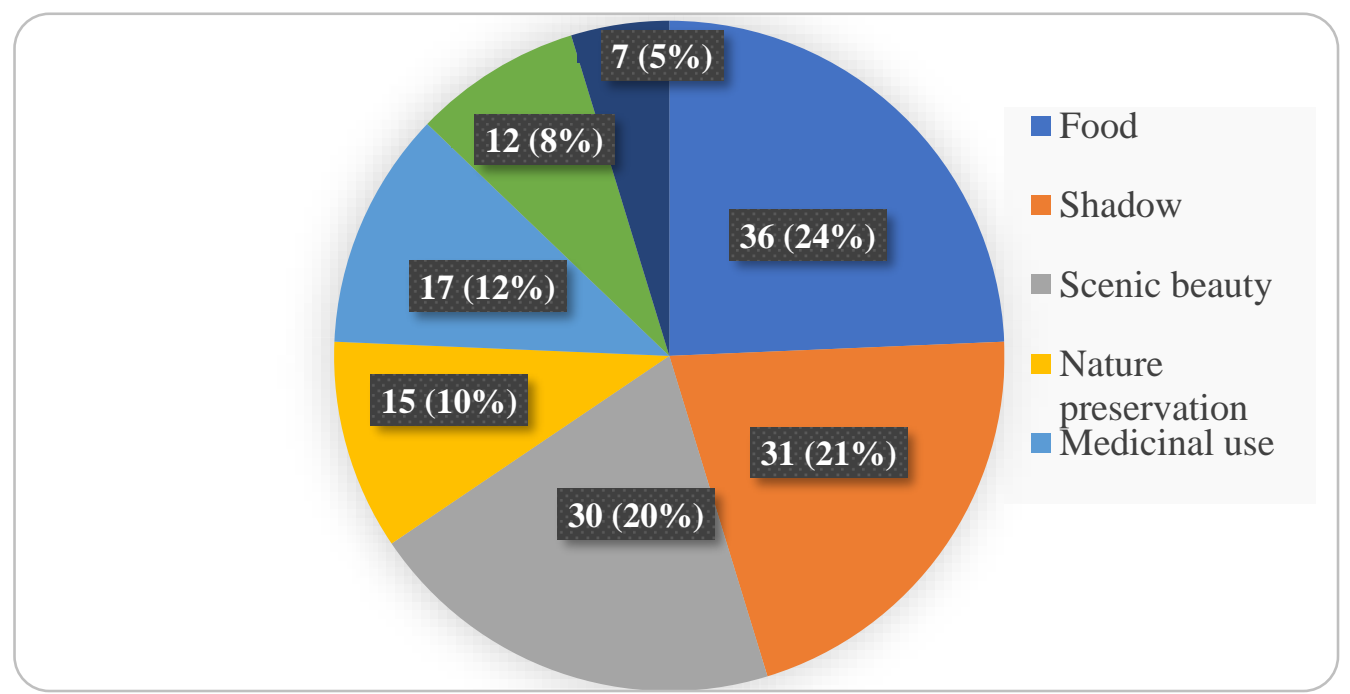

Source: Elaborated by the author

The main function reported by interviewees is related to the importance of tree species for food. Of 92 tree species identified in the lots, 52 are related to food insurance, they are food and medicinal (one is used for timber) species and, of these, 40 are already consumed by the families within the lots (Table 1).

It is also important to note that many of the motivations are related to the well-being of families (scenic beauty and shade, for example). There is also importance in the religious use of some species, which shows their relationship with the local culture and livelihood.

Framework 1 - Food, medicinal and timber species (and their families) planted and maintained by farmers in Rural Settlements in Araras-SP, total number of lots where they occur (from a total of 16 lots) and their function, according to interviewees ( $\mathrm{F}=$ Food species; $\mathrm{M}=$ Medicinal species; $\mathrm{T}=$ Timber species; $\mathrm{N}=$ native; $\mathrm{E}=$ exotic $; \mathrm{NT}=$ naturalized species; $\mathrm{Comm}=$ 

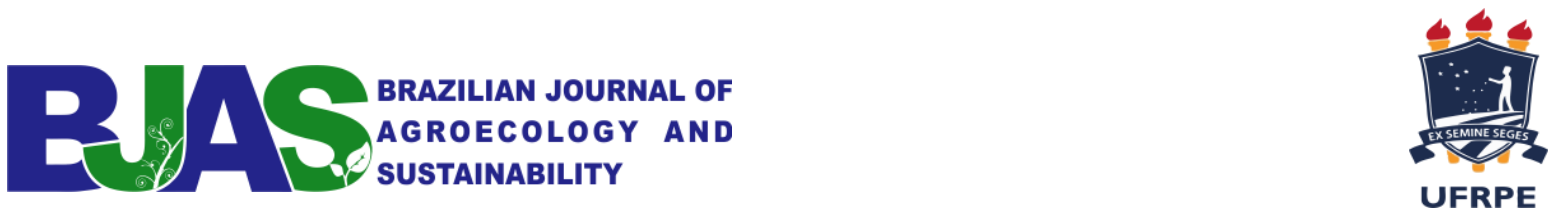

commercialized by farmers in local markets, in organized or informal channels). Species marked with $*$ are food species already consumed within the lots.

\begin{tabular}{|c|c|c|c|}
\hline Taxon & $\begin{array}{c}\text { Number } \\
\text { of lots }\end{array}$ & Main Uses & Comm. \\
\hline \multicolumn{4}{|l|}{ Anacardiaceae } \\
\hline *Anacardium occidentale L.(N) & 4 & $\mathrm{~F}, \mathrm{M}$ & $\mathrm{x}$ \\
\hline$*$ Mangifera $\mathrm{sp} .(\mathrm{E})$ & 16 & $\mathrm{~F}$ & $\mathrm{x}$ \\
\hline *Spondias dulcis Park. (E) & 2 & $\mathrm{~F}$ & \\
\hline *Spondias purpurea L. (E) & 8 & $\mathrm{~F}$ & $\mathrm{x}$ \\
\hline $\begin{array}{l}\text { *Spondias tuberosa } \\
\text { Arruda }(\mathrm{N})\end{array}$ & 3 & $\mathrm{~F}, \mathrm{M}$ & $\mathrm{x}$ \\
\hline \multicolumn{4}{|l|}{ Annonaceae } \\
\hline *Annona muricata L. (E) & 3 & $\mathrm{~F}$ & \\
\hline *Annona reticulata L. (E) & 4 & $\mathrm{~F}$ & \\
\hline \multicolumn{4}{|l|}{ Arecaceae } \\
\hline *Cocos nucifera L. (NT) & 9 & $\mathrm{~F}$ & $\mathrm{x}$ \\
\hline Elaeis guineenses Jacq. (NT) & 1 & $\mathrm{~F}$ & $\mathrm{x}$ \\
\hline \multicolumn{4}{|l|}{ Bixaceae } \\
\hline Bixa orellana $\mathrm{L} .(\mathrm{N})$ & 5 & $\mathrm{M}$ & $\mathrm{x}$ \\
\hline \multicolumn{4}{|l|}{ Caricaceae } \\
\hline *Carica papaya L. (E) & 11 & $\mathrm{~F}$ & $\mathrm{x}$ \\
\hline \multicolumn{4}{|l|}{ Ebenaceae } \\
\hline *Diospyros L. (N) & 1 & $\mathrm{~F}$ & \\
\hline \multicolumn{4}{|l|}{ Fabaceae } \\
\hline Cajanus cajan (L.) Huth (E) & 3 & $\mathrm{M}$ & \\
\hline Copaifera langsdorffii Desf. (N) & 1 & $\mathrm{M}$ & \\
\hline Dipteryx alata Vogel $(N)$ & 1 & $\mathrm{~F}$ & \\
\hline Hymenaea courbaril L. (N) & 3 & $\mathrm{~F}$ & \\
\hline Ingá sp. Miil (N) & 3 & $\mathrm{~F}$ & \\
\hline *Tamarindus indica L. (E) & 1 & $\mathrm{~F}$ & \\
\hline \multicolumn{4}{|l|}{ Lauraceae } \\
\hline *Cinnamomum verum J.Presl (E) & 1 & $\mathrm{M}$ & \\
\hline *Persea americana Mill. (NT) & 14 & $\mathrm{~F}$ & $\mathrm{x}$ \\
\hline \multicolumn{4}{|l|}{ Lecythidaceae } \\
\hline *Bertholletia excelsa Bonpl. (N) & 1 & $\mathrm{~F}$ & \\
\hline \multicolumn{4}{|l|}{ Lythraceae } \\
\hline *Punica granatum L. (E) & 2 & $\mathrm{M}$ & \\
\hline \multicolumn{4}{|l|}{ Malpighiaceae } \\
\hline *Malpighia emarginata D.C. (E) & 15 & $\mathrm{~F}$ & $\mathrm{x}$ \\
\hline \multicolumn{4}{|l|}{ Malvaceae } \\
\hline Ceiba pentandra (L.) Gaertn. (N) & 1 & $\mathrm{M}$ & \\
\hline *Hibiscus $\mathrm{sp} . \quad(\mathrm{E})$ & 3 & $\mathrm{M}$ & $\mathrm{x}$ \\
\hline \multicolumn{4}{|l|}{ Moraceae } \\
\hline *Artocarpus heterophyllus Lam. & 9 & $\mathrm{~F}$ & $\mathrm{x}$ \\
\hline *Ficus carica L. (E) & 2 & $\mathrm{~F}$ & \\
\hline *Morus nigra L. & 12 & $\mathrm{~F}, \mathrm{M}$ & $\mathrm{x}$ \\
\hline \multicolumn{4}{|l|}{ Moringaceae } \\
\hline Moringa oleífera Lam. (E) & 1 & $\mathrm{M}$ & $\mathrm{x}$ \\
\hline \multicolumn{4}{|l|}{ Musaceae } \\
\hline *Musa sp. (NT) & 15 & $\mathrm{~F}$ & $\mathrm{x}$ \\
\hline
\end{tabular}




\begin{tabular}{|c|c|c|c|}
\hline Taxon & $\begin{array}{l}\text { Number } \\
\text { of lots }\end{array}$ & Main Uses & Comm. \\
\hline \multicolumn{4}{|l|}{ Myrtaceae } \\
\hline $\begin{array}{l}\text { *Campomanesia xanthocarpa (Mart.) O.Berg } \\
(\mathrm{N})\end{array}$ & 1 & $\mathrm{~F}$ & \\
\hline $\begin{array}{c}\text { *Pimenta pseudocaryophyllus (Gomes) } \\
\text { Landrum (N) }\end{array}$ & 2 & $\mathrm{M}$ & \\
\hline Eucalyptus sp. (E) & 5 & $\mathrm{~T}$ & $\mathrm{x}$ \\
\hline *Eugenia uniflora L. $(\mathrm{N})$ & 11 & $\mathrm{~F}, \mathrm{M}$ & \\
\hline *Eugenia uvalha C. (N) & 5 & $\mathrm{~F}, \mathrm{M}$ & $\mathrm{x}$ \\
\hline $\begin{array}{c}\text { *Myrciaria glazioviana (Kiaersk.) G. Barroso } \\
\text { \& Sobral (N) }\end{array}$ & 1 & $\mathrm{~F}$ & \\
\hline *Myrciaria jaboticaba (Vell.) Berg $\quad(\mathrm{N})$ & 11 & $\mathrm{~F}$ & $\mathrm{x}$ \\
\hline *Myrcia tomentosa (Aubl.) DC. (N) & 1 & $\mathrm{~F}$ & \\
\hline *Psidium cattleyanum $(\mathrm{N})$ & 1 & $\mathrm{~F}$ & \\
\hline *Psidium guajava L. (NT) & 12 & $\mathrm{~F}, \mathrm{M}$ & $\mathrm{x}$ \\
\hline *Syzygium jambos $(\mathrm{L}) \quad.(\mathrm{NT})$ & 9 & $\mathrm{~F}$ & $\mathrm{x}$ \\
\hline \multicolumn{4}{|l|}{ Oxalidaceae } \\
\hline *Averrhoa carambola L. (NT) & 2 & $\mathrm{~F}$ & \\
\hline \multicolumn{4}{|l|}{ Rhamnaceae } \\
\hline Rhamnus purshiana DC. (E) & 1 & $\mathrm{M}$ & \\
\hline \multicolumn{4}{|l|}{ Rosaceae } \\
\hline *Eriobotrya japonica (Thunb.) Lindl. (NT) & 3 & $\mathrm{~F}$ & \\
\hline *Prunus avium L. (E) & 1 & $\mathrm{~F}$ & \\
\hline *Prunus persica (L.) Batsch (E) & 4 & $\mathrm{~F}$ & \\
\hline \multicolumn{4}{|l|}{ Rubiaceae } \\
\hline Coffea sp. (NT) & 3 & $\mathrm{~F}$ & \\
\hline Genipa americana L. (N) & 2 & $\mathrm{~F}$ & \\
\hline \multicolumn{4}{|l|}{ Rutaceae } \\
\hline *Citrus sp. 1 (E) & 13 & $\mathrm{~F}, \mathrm{M}$ & $\mathrm{x}$ \\
\hline *Citrus sp. 2 (E) & 5 & $\mathrm{~F}$ & $\mathrm{x}$ \\
\hline \multicolumn{4}{|l|}{ Sapindaceae } \\
\hline *Litchi chinensis Sonn. (E) & 1 & $\mathrm{~F}$ & $\mathrm{x}$ \\
\hline *Talisia esculenta (A. St.-Hill) Radlk (N) & 1 & $\mathrm{~F}$ & \\
\hline \multicolumn{4}{|l|}{ Solanaceae } \\
\hline *Solanum paniculatum L. (N) & 1 & $\mathrm{~F}, \mathrm{M}$ & \\
\hline \multicolumn{4}{|l|}{ Vochysiaceae } \\
\hline Vochysia tucanorum Mart. (N) & 1 & $\mathrm{M}$ & \\
\hline
\end{tabular}

Source: Elaborated by the author.

Fruit trees-based systems play an important role in the livelihood improvement and provide multiple contributions of household income and supplementary food for smallholder farmers (Adane et al., 2019). Considering sustainable rural livelihood as the "maintenance or enhancement of access of rural families to food and income-generating activities on a long-term basis", perennial components as trees, performing many different functions inside the farms, surely can contribute to it. Farmers in our study use the species mainly for family consumption, complementing the family's diet and valuing their food, but also make sales to assist in the generation of income (Figure 3). Degrande et al. (2006) and Ndayambaje, Heijman and Mohren 

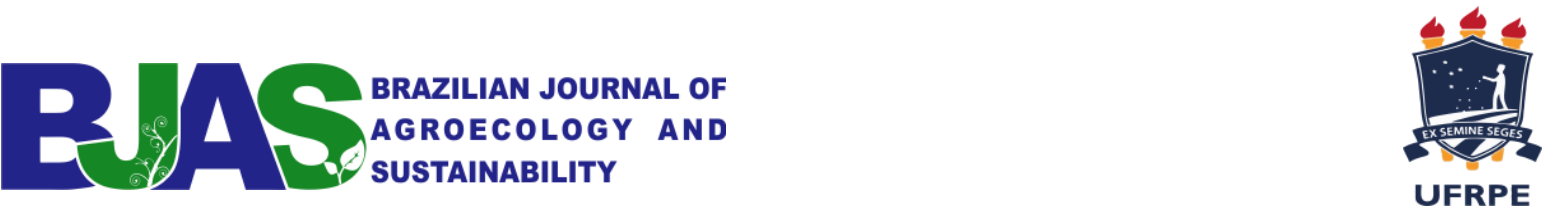

(2012) reported that fruit trees stand out, because in addition to meeting the needs for food and firewood, they are also a source of extra income for farmers who are more motivated to plant them. The interviewees also highlighted the importance of these species, as they also generate food security.

Figure 3 - Map with the number of tree species used for commercialization and the number of species used for food or medicinal purposes in the studied lots of rural settlements (Araras-SP, Brazil).

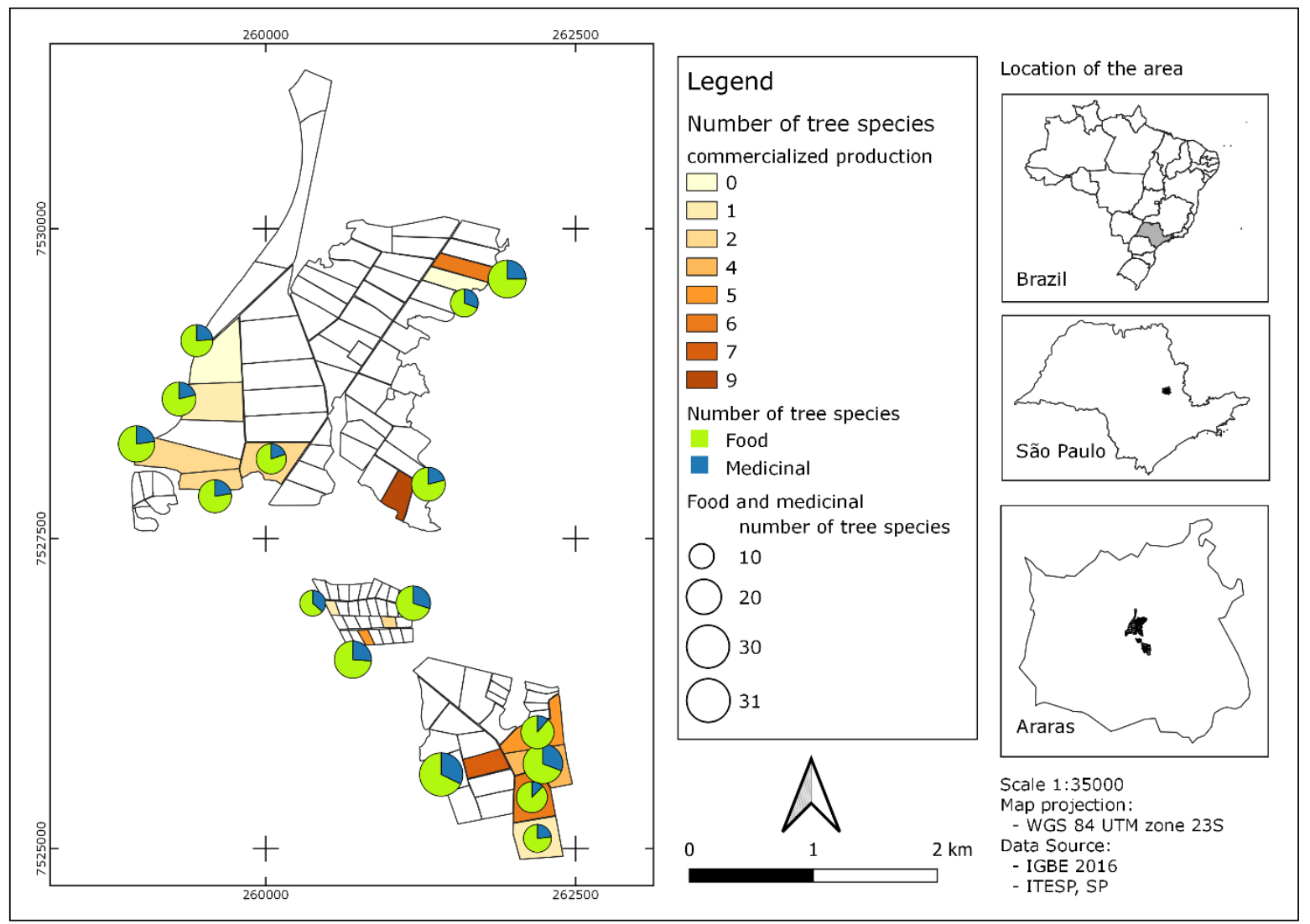

Source: Elaborated by the author.

Trees are present in several arrangements within the lots, with the majority organized in tree nuclei (clusters of two or more trees), and close to the houses, to facilitate the access to food species. Only in four lots they are arranged in a commercial plots pattern. These are Musa sp., Citrus sp., Moringa oleifera Lam., Eucalyptus sp., Persea americana Mill., considered here as "flagship species" (Ferreira, Pompeu, Fonseca, \& Santos, 2015) in these lots' production systems.

According to Oli et al. (2015) smallholders farmers maintain and plant trees specially to promote food resources and supplement their income. From all food, medicinal and timber species, twenty-three provide products that are already marketed by farmers (Table 1). 

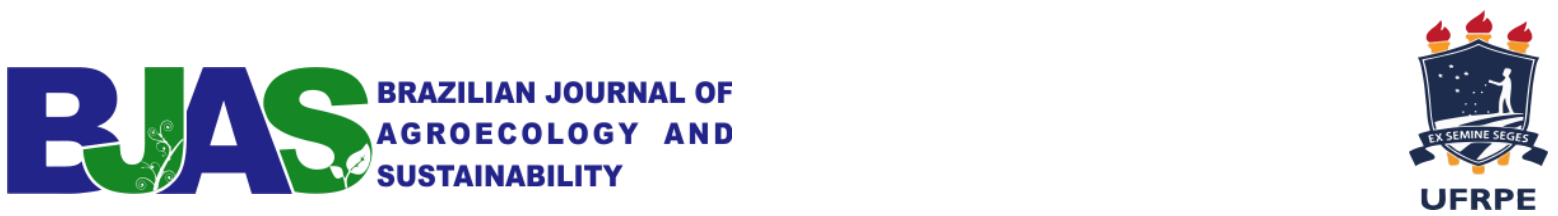

The most frequently planted species (Mangifera sp., Carica papaya L., Persea americana Mill., Malpighia emarginata D.C., Morus nigra L., Musa sp., Psidium guajava L., Citrus sp., Myrciaria jaboticaba (Vell.) Berg) are all commercialized. These are all exotic species (except Myrciaria jaboticaba) that are well known and have a consolidated consumer market. Only Eugenia uniflora was mentioned by 11 settlers and is not commercialized, perhaps because it is a native species that does not have a very consolidated consumer market.

We found that trees contribute to the generation of income in the lots, their products are sold by farmers weekly and monthly (depending on the growing and production seasons of each species), in different channels (Figure 4).

Figure 4 - Commercialization channels for tree products, cited by settled farmers in the study area (Araras-SP, Brazil).

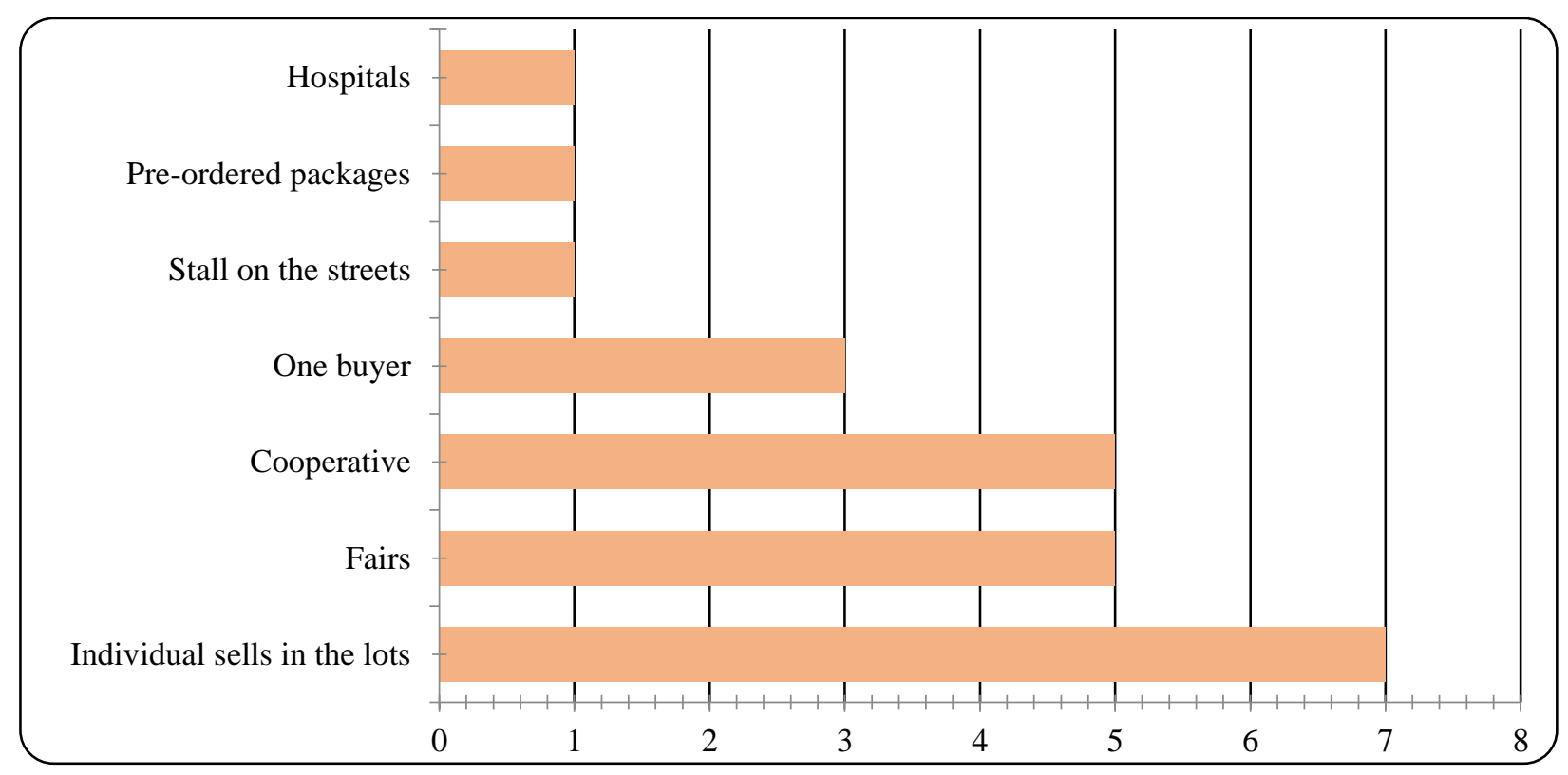

Source: Elaborated by the author.

The Figure 4 show that most settlers sell their products individually on their own lots, one portion sell productos in fairs, another portion in cooperatives. A little portion sell products to one buyer (specially Eucalyptus and Moringa products) who acquires their entire production. In other lots, the producers themselves find different ways and places to commercialize their products. Only in two lots there are no sales of tree products.

A considerable portion of settlers sell (25\%) at local fairs, but still individually. Feito (2020) highlights the importance of alternative channels for marketing products from family farming, in a study conducted in Argentina. This author (Feito, 2020) recognized that these fairs 

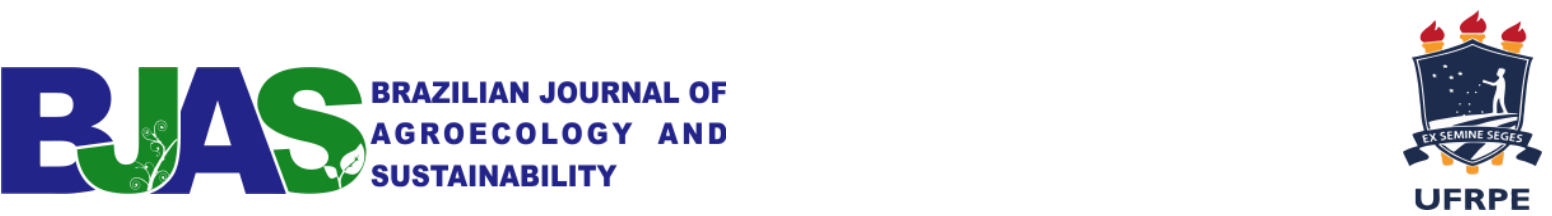

contribute to rural development as a powerful alternative marketing instrument for the sector, improve exchanges between actors, reflected in the increase in social capital.

From the total settlers only $4(25 \%)$ sell their products through cooperatives, that is, collectively organized. These sales happen monthly and involve a lot of products, because this cooperative serves governmental programs such as the PNAE - National School Feeding Program. This initiative is especially important, because it manages to sell products in larger quantities.

Robles (2019), studying cooperativism within the social movement "Movimento dos Trabalhadores Sem Terra / Landless Workers Movement" [MST] -, registered a presence of 146 cooperatives, in the period from 1985 to 2016. The author (Robles, 2019) showed that regions with more cooperatives were in Brazil's northeast and south. In the State of São Paulo (in the country's southeast region), there were in this period only 8 established cooperatives, with only 4 working with commercialization. This shows that in São Paulo State, where the study areas are located, it has always been difficult to establish and maintain cooperatives on the part of settlers linked to social movements. Authors point out that "cooperativism" represents an important initiative by farmers and settlers, emphasizing that this initiative does not always had gotten the sympathy of the State, varying between different governments and their respective party policies. The author concluded that the actions of this social movements linked agrarian reform and agricultural cooperativism, to advance political and economic democracy. By the author (Robles, 2019) the it was able to build a transformative cooperative project capable of reducing structural poverty, enhancing political citizenship, and promoting environmental stewardship. According to Robles (2019) despite all these advances, the longterm sustainability of this cooperative project depends significantly on these movements' ability to overcome structural barriers and, more importantly, obtain long-term support from state and non-state actors.

In the current period (2018/2019) the current government has no sympathy for social movements and has not encouraged any form of cooperativism, which may explain the low engagement in cooperatives by the settlers studied in Araras - SP.

According to Clark and Martinez:

\footnotetext{
“One option for sustaining smallholder peasant agriculture and diversified agricultural production systems in is improved access to niche markets - or new markets - however a common pre-requisite to enter these markets is private third party agricultural certification" (Clark \& Martínez, 2016, p. 292).
} 

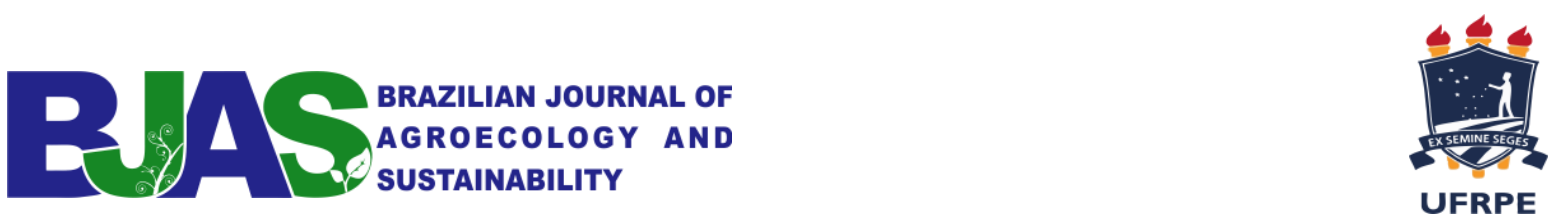

Perhaps an alternative to increase the marketing of products from the settlements of Araras - SP would be certification, however, as emphasized by the authors of a study conducted in Spain, the most agricultural certification initiatives (such as organic and Fairtrade) are private initiatives that are costly for small-producers with limited access to capital (Clark \& Martínez, 2016) so, these small farmers without any initial subsidy (public or from other sources) would not be able to obtain these certifications and access these new markets.

\section{FINAL CONSIDERATIONS}

The reasons why small settled farmers maintain, or plant trees are multiple, however, to a large extent, they are motivated by direct use (food) or the possibility of generating income through the sale of products. Of the 92 tree species planted or maintained, approximately half of them have food and medicinal uses (just one is used as timber), and approximately $45 \%$ of these species are commercialized by farmers, indicating their importance for their farming and livelihoods.

The species that add the most value and provide the greatest income are those that have a consolidated market (generally they are exotic species). One native species that is frequently planted (Eugenia uniflora) is not yet commercialized, indicating that the market for it is still incipient, or that it needs education and dissemination actions to encourage or establish new channels for its commercialization.

The results also allow us to conclude that the forms of commercialization are still predominantly isolated, individual, and often informal, with few collective marketing initiatives, as in cooperatives that can guarantee sales on a larger scale.

In our study, tree species play an extremely important role in the lives of the settlers and their families and can promote - through the diversification of productive systems - their resilience and permanence in the field, and valorize family farming through the production of food and income generation. As a result, it becomes essential to motivate farmers to plant and maintain trees in their lots, and to raise awareness of its multiple benefits, as they are essential as strategies for source of income and improvement of food and quality of life.

We conclude that tree species have potential to be inserted in local productive systems, helping in the sustainability of lots (or agroecosystems) in agrarian reform settlements. 


\section{REFERENCES}

Adane, F., Legesse, A., Weldeamanuel, T., \& Belay, T. (2019, January 10). The contribution of a fruit tree-based agroforestry system for household income to smallholder farmers in Dale District, Sidama Zone, Southern Ethiopia. Adv Plants Agric Res., 9(1), 78-84. doi: 10.15406/apar.2019.09.00415.

Altieri, M. A. (2002, December). Agroecology: the science of natural resource management for poor farmers in marginal environments. Agriculture, Ecosystems and Environment, 93(1-3), 1-24. doi: 10.1016/S0167-8809(02)00085-3.

Bozzo, I. T., \& Figueiredo, R. A. (2018, August 01). A implementação de princípios agroflorestais e sua importância no desenvolvimento dos agroecossistemas: experiência no assentamento Santa Helena, São Carlos (SP). Retratos de Assentamentos, $21 \quad$ (2), 86-105. doi: 10.25059/25272594/retratosdeassentamentos/2018.v21i2.325.

Chirwa, P. W., \& Mala, W. (2016, July 21). Trees in the landscape: towards the promotion and development of traditional and farm forest management in tropical and subtropical regions. Agroforestry Systems, 90, 555-561. doi: 10.1007/s10457-016-9987-y.

Chan, K. M., Gold, R. K., \& Pascual, U. (2018, December 07). Editorial overview: Relational values: what are they, and what's the fuss about? Current Opinion in Environmental Sustainability, 35, A1-A7. doi: 10.1016/j.cosust.2018.11.003.

Clark, P., \& Martinéz, L. (June 2016). Local alternatives to private agricultural certification in Ecuador: Broadening access to 'new markets'? Journal os Rural Studies, 45, 292-302. doi: 10.1016/j.jrurstud.2016.01.014.

Colfer, C. J. P., Achdiawan, R., Adnan, H., Moeliono, M., Mulyana, A., Mulyoutami, E., Roshetko, J. M., Yuliani, E. L., Balang, \& LepMil. (2015, October 22). Preparing the ground for better landscape governance: gendered realities in southern Sulawesi. Forests, Trees and Livelihoods, 24(1), 59-83. doi: 10.1080/14728028.2014.951002.

Cooper, N., Bradyc, E., Steend, H., \& Bryced, R. (2016, October 04). Aesthetic and Spiritual Values of Ecosystems: Recognising the Ontological and Axiological Plurality of Cultural Ecosystem Services. Ecosystem Services, 21, 218-229. doi: 10.1016/j.ecoser.2016.07.014.

Cruz, N. N. D. (2008). Modos de vida e territorialidades nos assentamentos de reforma agrária. $R A$ 'EGA, 16, 93-100. doi: 10.5380/raega.v16i0.12680.

Degrande, A., Schreckenberg, K., Mbosso, C., Anegbeh, P., Okafor, V., \& Kanmegne, J. (2006, June). Farmers' fruit tree growth strategies in the humid forest zone of Cameroon and Nigeria. Agroforestry Systems, 67(2), 159-175. doi: 10.1007/s10457005-2649-0.

Duque-Brasil, R., Soldati, G. T., Costa, F. V., Marcatti, A. A., Reis Jr, R., \& Coelho, F. M. G. (2011, September 24). Composição, uso e conservação de espécies arbóreas em 

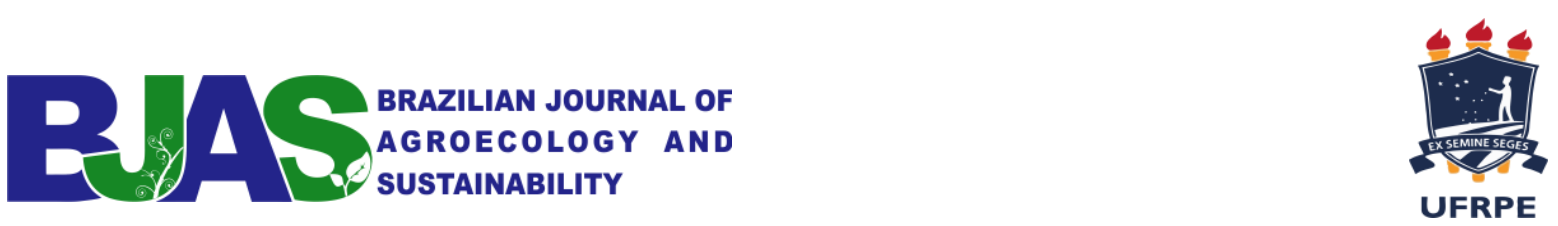

quintais de agricultores familiares na região da mata seca norte-mineira, Brasil. Sitientibus Série Ciências Biológicas, 11(2), 287-297.

Farias, M. H. C. S., Beltrão, N. E. S., Santos, C. A., \& Cordeiro, Y. E. M. (2018, May 15). Impacto dos assentamentos rurais no desmatamento da Amazônia. Mercator, 17, 1-20. doi: $10.4215 / \mathrm{rm} 2018 . e 17009$.

Feito, M. C. (April, 2020). Comercialización de la agricultura familiar para el desarrollo rural: feria de la Universidad Nacional de la Matanza. Revista de Economia e Sociologia Rural, 58(1), e187384. doi:10.1590/1806-9479.2020.187384.

Ferreira, D. C. F., Pompeu, G. S. S., Fonseca, J. R., \& Santos, J. C. (2015, February 18). Sistemas agroflorestais comerciais em áreas de agricultores familiares no município de Altamira, Pará. Revista Brasileira de Agroecologia, 9(3), 104-116.

Fundação Instituto de Terras do Estado de São Paulo "José Gomes da Silva". (2007). Assentamentos: Situação quanto a localização municipal. Recovered in: April 21, 2019 in http://www.itesp.sp.gov.br.

Herrera, L. P., Sabatino, M. C., Jaimes, F. R., \& Saura, S. (2017, August 28). Landscape connectivity and the role of small habitat patches as stepping stones: an assessment of the grassland biome in South America. Biodiversity and Conservation, 26(14), 34653479. doi: 10.1007/s10531-017-1416-7.

Ingram, V., Levang, P., Cronkleton, P., Degrande, A., Leakey, R., \& Damme, P. V. (2014, March 14). Forest and tree product value chains. Forests, Trees and Livelihoods, 23(12), 1-5. doi: 10.1080/14728028.2014.892756.

Instituto Brasileiro de Geografia e Estatística. (2010). Informações sobre os Municípios Brasileiros: Cidades. Recovered in May 07, 2020 in http://www.ibge.gov.br.

Instituto Brasileiro de Geografia e Estatística. (2017). Censo Agropecuário 2017. Recovered in: May 07, 2020 in https://sidra.ibge.gov.br/pesquisa/censoagropecuario/censo-agropecuario-2017.

Mbow, C., Noordwijk, M. V., Luedeling, E., Neufeldt, H., Minang, P. A., \& Kowero, G. (2013, November 17). Agroforestry solutions to address food security and climate change challenges in Africa. Current Opinion in Environmental Sustainability, 6, 6167. doi: 10.1016/j.cosust.2013.10.014.

Miranda, L. A., \& Carmo, M. S. (2009, June 23). Recursos florestais no assentamento 12 de outubro (Horto Vergel), Mogi Mirim, SP. Revista Árvore, 33(6), 1085-1093. doi: 10.1590/S0100-67622009000600011.

Ndayambaje, J. D., Heijman, W. J. M., \& Mohren, G. M. J. (2012, January 22). Household determinants of tree planting on farms in rural Rwanda. Small-scale Forestry, 11, 477508. doi: 10.1007/s11842-012-9196-0. 
O'Farrell, P. J., \& Anderson, P. M. L. (2010, February 22). Sustainable multifunctional landscapes: a review to implementation. Curr Opin Environ Sustain, 2(1-2), 59-65. doi: 10.1016/j.cosust.2010.02.005.

Oli, B. N., Treue, T., \& Larsen, H. O. (2015, April 29). Socio-Economic Determinants of growing trees on farms in the middle hills of Nepal. Agroforestry Systems, 89, 765777. doi: 10.1007/s10457-015-9810-1.

Piasentin, F. B., Saito, C. H., \& Sambuichi, R. H. R. (2014 July-September). Preferências locais quanto às árvores do Sistema Cacau-cabruca no Sudeste da Bahia. Ambiente \& Sociedade, 17(3), 55-78.

Ramos Filho, L. O., Szmrecsányi, T., \& Pellegrini, J. B. R. (2010). Biodiversidade e reforma agrária: uma experiência agroecológica na região canavieira de Ribeirão Preto, Brasil. Retratos de Assentamento, 13, 207-238.

Robles, W. (2019, June). The politics of agicultural cooperativism in Brazil: A case study of the landless rural worker movement (MST). Journal of Co-operative Organzation and Management, 7(1), 10-25. doi: 10.1016/j.jcom.2019.02.001.

\section{ACKNOWLEDGMENTS}

We thank the Coordination for the Improvement of Higher Education Personnel - Brazil (CAPES) - Financing Code 001 and the residents of rural settlements in Araras, São Paulo, Brazil. 